Chirurgia (2019) 114: 571-578

No. 5, September - October

Copyright@ Celsius

http://dx.doi.org/10.21614/chirurgia.114.5.571

\title{
Gastric Metastasis of Invasive Lobular Breast Carcinoma, a Current Diagnostic and Treatment Challenge - A Review
}

\author{
Rodica Birla', Daniela Dinu', Cristina losif ${ }^{2}$, Silviu Constantinoiu' \\ ${ }^{1}$ General and Esophageal Surgery Department, Center of Excellence in Esophageal Surgery, Sf. Maria Clinical Hospital, Bucharest \\ 2Pathology Department, Sf. Maria Clinical Hospital, Bucharest
}

Corresponding author:

Rodica Birla, MD

General and Esophageal Surgery Department, Center of Excellence in Esophageal Surgery, Sf. Maria Clinical Hospital, Bucharest

E-mail: birlarodica@ahoo.com

\section{Rezumat}

Metastaza gastrică a carcinomului de sân lobular invaziv, o provocare actuală de diagnostic și tratament - o revizuire a literaturii

Introducere: Predilecția metastazei cancerului invaziv lobular de sân pentru stomac este un subiect care a ridicat diverse discuții de-a lungul timpului.

Istoric şi Obiective: Metastaza gastrică a cancerului lobular de sân este neobişnuită şi poate fi diagnosticată după o perioadă lungă de timp de la diagnosticul de tumoră primară. Scopul acestui studiu a fost de a revizui cunoştințele actuale cu privire la metodele actuale de diagnostic şi tratament al metastazelor gastrice ale cancerului de sân.

Metoda: O căutare sistematică a literaturii a fost efectuată în baza de date Pub-Med -Medline folosind termenii „metastaza gastrică a cancerului de sân lobular” şi „caracteristici ale metastazelor gastrice" pentru a identifica articole relevante pentru metastaza gastrică a cancerului de sân lobular.

Rezultate: Mai multe lucrări au arătat că subiectul este rar prezentat fie sub formă de prezentări de caz sau miniserii prin rezumarea cazurilor sporadice. Datorită rarității şi specificității metastazelor ca tip de gazdă şi aspectul de latență după cancerul lobular de sân, metastaza gastrică este considerată atipică şi ocazional confundată cu o malignitate primară a stomacului. Cele mai recente articole prezintă criteriile de diagnostic imunohistochimice ale acestei entități clinice şi o nouă abordare terapeutică. Concluzii: La pacienții cu metastază gastrică a cancerului de sân lobular, obținerea de material patologic şi interpretarea biopsiilor poate fi o adevărată provocare pentru obținerea unui diagnostic 
patologic corect, imunohistochimia ne oferă un diagnostic de certitudine. Introducerea unui protocol de supraveghere endoscopică pentru pacienții cu cancer lobular de sân ar putea fi o propunere pentru detectarea precoce a metastazelor gastrice care să permită o terapie adecvată.

Cuvinte cheie: metastaze gastrice, cancer de sân lobular, teste imunohistochimice, endoscopie superioară

\begin{abstract}
Introduction: The predilection of lobular invasive breast cancer metastasis for the stomach is a topic that has succumbed to various assumptions over the time.

Background and Aims: Gastric metastasis of lobular breast cancer is unusual and it can be diagnosed after a long period of time from primary tumor diagnosis. The aim of this study was to review current knowledge regarding the current methods of diagnosis and treatment of gastric metastasis of breast cancer.

Methods: A systematic literature search was performed in the Pub-Med -Medline database using the terms "gastric metastasis of lobular breast cancer" and "gastric metastasis features" to identify articles relevant to gastric metastasis of lobular breast cancer.

Results: Several papers have shown that the topic is rarely presented in the form of case presentations or miniseries by summing up sporadic cases. Due to its rarity and metastasis specificity as host type and appearance after latency of lobular breast cancer makes its gastric metastasis considered atypical and occasionally confused with a primary stomach malignancy. The most recent articles present the immunohistochemical diagnostic criteria of this clinical entity and a new therapeutic approach.

Conclusion: At patients with gastric metastasis of lobular breast cancer, obtaining pathologic material and biopsies interpretation can be a real challenge for getting a correct pathologic diagnosis, immunohistochemistry gives us definite diagnosis. The introduction of an endoscopic surveillance protocol for patients with lobular breast cancer could be a proposal for the detection of early gastric metastases allowing for appropriate therapy.
\end{abstract}

Key words: gastric metastases, lobular breast cancer, immunohistochemistry test, upper endoscopy

\section{Introduction}

Breast cancer has one of the highest incidence rates in the last years with a increasing trend and it is a leading cause of cancer-associated mortality worldwide in women (1).

Owing to the advances in management of breast cancer, overall survival rates have increased; but, these therapies have not produced significant changes in the prognosis of patients with breast metastases. Distant metastases rather than the primary tumour itself are the cause of death, almost $90 \%$ of breast cancer-related deaths are due to tumour dissemination (2).

The incidence of gastrointestinal metastases based on the results of autopsy series was estimated by some authors to be approximately $4-35 \%$ (3). Gastrointestinal metastases can sometimes be seen in patients with cancers of the breast, kidney, lung and malignant melanoma. Breast cancer is the second type of cancer which determines gastrointestinal metastasis, after lung cancer (4). McLemore reported gastro-intestinal metastases in $0,3 \%$ of the 12001 patients diagnosed as breast cancer (5). 


\section{Epidemiology}

Stomach is an uncommon site for tumour metastasis, with an incidence of $0.2-1.7 \%$, with the most frequent primaries being in the lung, breast, or melanoma $(6,7)$.

Through long-term follow-up and postmortem studies, the incidence of gastric metastases of breast cancer was estimated at $2-18 \%(8,9)$.

The invasive lobular cancer that represents 5\%-10\% of primary breast cancers, frequently involves unusual metastatic sites such as the gastrointestinal tract, the gynaecological organs, the peritoneum and meninges (10-14) in contrast to the invasive ductal cancer that follows the more conventional metastatic pattern of breast cancers and metastasizes in liver, lungs and brain $(15,16)$.

Breast cancer pathologic subtypes which had metastasis of gastrointestinal tract are often invasive lobular more than invasive ductal carcinomas (17). Invasive lobular carcinoma or luminal-type breast cancer (ER positive) tends to metastasize to the stomach at a higher frequency compared with other types of breast cancer $(18,19,20)$.

Some authors showed in a mini serie that ninety-seven percent of gastric metastasis from breast cancers are derived from invasive lobular carcinoma (21).

\section{Pathogenesis}

The most cases described in literature on gastric metastasis of breast cancer simulate a primary gastric carcinoma. In these cases first described primary breast cancer and consequent metastases arise in part from disseminated tumoral cells originating from the primary tumour and from residual disease persisting after systemic therapy. Gastric metastasis may appear many years after the treatment for invasive lobular breast carcinoma. (10).

An explication could be the phenomenon of metastatic dormancy, associated with the presence of disseminated tumour cells with low proliferative and metabolic activities (22).
These cells are not capable of producing a secondary tumour at the time of sowing, but remain viable and can acquire invasive skills through genetic changes and interactions with the micro medium. This dormancy state could be a major problem limiting the efficacy of chemotherapy, which acts on active and proliferative target cells but does not eradicate latent metastases (23). Some authors support the idea that chemokines as well as inflammatory events seem to be implicated in metastasization process and they hypothesized that H. pylori, inflammatory cells, and chemokines might create a favorable environment attracting tumor cells (24).

\section{Diagnostic}

\section{Clinico-Imagistic Features}

Because current guidelines do not support a routine search for gastric metastases in patients with treated breast cancer, their clinical suspicion is difficult because their occurrence may be after a long period of time when the patient may be considered cured of breast cancer (25).

Gastric metastasis of breast cancer is rarely seen and it is very difficult to diagnose, perhaps because this is not our first hypothesis. But, anyway it is hard to differentiate from a primary gastric cancer on clinical, imagistical and pathological characteristics (26).

The patients, who have gastric metastasis of breast cancer, usually suffer from nonspecific gastrointestinal symptoms like indigestion, dyspepsia, anorexia, pyrosis, nausea, epigastric pain, early satiety, vomiting, bleeding and weight loss, often indistinguishable from the symptoms of a primary gastric cancer (27).

Radiological findings on computed tomography or barium studies are nonspecific, and may be hard to distinguish from primary gastric cancer (28).

The most common type of gastric metastasis of breast cancer is stiffness of the whole stomach such as in linitis plastica, while the type of discrete tumor or external compression is less common $(4,15)$. Some patients 
may present gastric perforation secondary to gastric metastasis from breast cancer (29).

Some authors reported in diagnosis of gastric metastasis the use of $18 \mathrm{~F}-2$-deoxy-2fluoro-D-glucose (FDG) positron emission tomography combined with computed tomography imaging that revealed FDG uptake across the thickness of the antral wall (30).

Another authors suggest that when we have a high index of clinical suspicion in those with non-specific gastric symptoms and a past history of invasive lobular breast cancer, an early endoscopy are recommended (31).

Endoscopic aspects are no specific to suggest gastric metastasis, they are diverse in terms of location, size, number, shape, and presence or absence of bleeding, erosion or ulceration, which can imitate early gastric cancer to advanced gastric cancer, and can be located anywhere from the fundus to the antrum, even in the lesser curvature and posterior wall side of the remnant stomach.

Incipient gastric lesions are most commonly referred to as primary gastric cancers. A case that was diagnosed as early gastric cancer discovered gastric metastasis of breast cancer using endoscopic biopsies (32), and another case revealed that definitive diagnosis of metastatic breast cancer was confirmed after endoscopic mucosal resection of a presumed primary early gastric carcinoma (33).

It is difficult to consider gastric metastasis, particularly in the setting of a solitary gastric lesion. Some authors noted that solitary gastric metastases are more common than multiple lesions, and are mainly located in the middle or the upper third of the stomach (4).

Other authors showed that the most common type of gastric metastasis of breast cancer $(73-83 \%)$ is linitis plastica (34-36).

Some authors think that patients with invasive lobular cancer of breast should undergo screening EGD regularly to detect gastric metastases early $(37,38)$.

\section{Pathologic Diagnostic}

A particular problem of gastric endoscopic biopsy occurs in patients with infiltrative gastric metastases. Initial biopsies in these cases can be normal in about $46-50 \%$ of the cases and demonstrate only discrete non-specific mucosal abnormalities indistinguishable from other tumours or benign disease, because invasion is often limited to the submucosa and seromuscular layers and is not detected by superficial biopsies, aspect that may delay the diagnosis for a while $(39,40)$.

Thus, it is suggested to perform deep and extensive biopsies and to repeat them if negative, for obtaining representative material $(41,42)$.

If biopsies obtained by repeated, standard or forced biopsy of the modified gastric mucosa do not contain enough malignant cells, biological material can be harvested by ultrasonographic guided fine needle aspiration $(43,44)$.

Perhaps the most important aspect in the diagnosis of the disease is the obtaining the pathological material and of course the interpretation of the results of pathological exam. Some authors suggest that the histological features of gastric biopsies should be compared with those of the primary breast tumour in order to confirm the diagnosis (45).

An interesting situation was presented by many authors in patients with lobular invasive cancers and gastric metastasis, of which gastric biopsies contains signet ring shaped cells in pathologic examination and for this reason it was mistakenly thought that these patients might have a primary gastric cancer that is signet ring cell type gastric carcinomas (46).

Other authors have suggested that breast ring cell carcinoma may have some morphological distinctions from gastric or colic ring cell carcinoma, such as the presence of an intracytoplasmic, circumscribed, eosinophilic, central vacuole in lobular breast cancer, while other carcinomas have a globular mucoid inclusion that pushes the nucleus to the periphery of the cell (47).

A common situation in literature was that the initial pathologic diagnosis was diffusetype gastric carcinoma, evaluated by pathologic exam of gastric endoscopic or ultra- 
sonographic biopsy and the definitive diagnosis of metastatic breast cancer was confirmed after subtotal gastrectomy for a presumed primary gastric carcinoma and was obtained using a panel of specific immunohistochemically markers $(48,49)$.

\section{Immunohistochemically and Molecular Diagnostic}

Detailed immunohistochemically analysis is the only relevant method for distinction between metastatic and primary gastric carcinoma, taking into account that metastases of lobular cancer generally keep approximately the same receptor status as the primary breast carcinoma (50-52).

The lobular cancer cells are usually, oestrogen receptor (ER) and progesterone receptor (PGR) positive, without overexpression or amplification of the human epidermal growth factor receptor 2 (HER-2/neu) gene.

Some authors reported that metastatic breast carcinoma is usually positive for cytokeratin 7 (CK7) (90\%), gross cystic disease fluid protein 15 (GCDFP-15), carcinoembryonic antigen (CEA), ER and PGR, and negative for cytokeratin 20 (CK20). Other studies outlined that CK20 demonstrates to be especially positive in gastric, colonic, pancreatic and in transitional cell carcinomas, while it is not noted in breast carcinomas (53-56).

ER and PRG receptors can be used to distinguish the metastatic breast cancer. First-generation antibodies against $\operatorname{ER~} \beta$ are no longer used in standard practice. Using the second-generation antibodies against ER $\alpha$ some authors concluded that ER $\alpha$ expression can be used to diagnose gastric metastasis of breast cancer, because no primary gastric tumour expressed ER $\alpha$.

Another immunohistochemically marker studied is E-cadherin, some authors observed that the lack of E-cadherin expression was related to metastatic lobular breast cancer $(57,58)$. Around $90 \%$ of invasive lobular breast cancers present E-cadherin loss (59).

Some authors consider that loss of E-cadherin expression explains the unique histopathological features lobular breast cancer
- these tumours are composed of relatively small, infiltrating and discohesive epithelial cells and do not form a well-defined mass, resembling the diffuse gastric cancer cells phenotype - a possible explanation of confusion with primary gastric cancer in the absence of immunohistochemical tests (60).

Another authors assumed that atypical pattern of metastases in invasive lobular cancers can be by virtue of loss of expression of epithelial E-cadherin (57), but metastasis of the digestive tract is a complex process and it is quite poorly explained at this time.

In the immunohistochemically evaluation, some authors reported that mammoglobulin and GCDFP-15 positive suggest metastases caused by breast cancer (4).

\section{Therapeutic Approach}

It appears that the occurrence of gastric metastases after lobular breast cancer would be related to adjuvant postoperative treatment.

Some author noticed that adjuvant systemic therapy with tamoxifen reduces the rate of relapse and improves survival both during and after 5 years of therapy in women with ER positive early stage breast cancer (61).

Some trials (NCIC CTG Ma17) recommended extending adjuvant hormonal therapy with an aromatase inhibitor (oestrogen synthetase), letrozole, for an additional 5 years after the first 5 years therapy with tamoxifen (62). A subsequent analysis of this trial showed that1-7 years after 5 years of tamoxifen treatment women still have a significant recurrence risk and this risk was markedly reduced by introducing delayed letrozole treatment up to 11 years and 16 years from diagnosis (61).

It further supports the idea of persistent or latent metastases occurring many years after the primary presentation of breast cancer. From the results of this trial, it can be concluded that despite the 5-year tamoxifen adjuvant treatment, women may continue to host latent clinical micro-metastases that are generally susceptible to antioestrogen therapy, regardless of the time of application of this therapy $(61,62)$. 
Meanwhile, long-term therapy, especially hormone-dependent breast cancer like lobular type, becomes a standard of care and the benefit to a small proportion of women at risk of late recurrence must be balanced against the risk of side-effects due to long-term treatment.

Improving the systemic therapies that are applied immediately after primary treatment of breast tumour is the safest way for longterm prophylaxis of metastases.

When gastric metastases of breast cancer appeared, it is crucial to obtain the right diagnosis in order to initiate the appropriate treatments - metastases treatments vs. treatment of a new tumour. Gastric metastasis of invasive lobular breast cancer represents evidence of systemic disease and systemic therapy, such as chemotherapy and/or hormonal therapy, rather than surgical resection is indicated $(27,39,62,63)$.

In some cases or small series of patients with this disease, chemotherapy or endocrine therapy led to a evident palliative effect in only $30-50 \%$ of patients receiving systemic therapy with no evident difference in response rates between endocrine therapy and chemotherapy; the median survival of the patients from diagnosis of gastric metastases moment was $11-28$ months $(44,45,64,65,66)$.

Some authors recommended surgical treatment in the case of solitary gastric metastasis, followed by chemotherapy and hormonal therapy, surgical resection in these cases bringing survival benefit $(67,68)$ or when gastric metastasis was the first symptom of lobular breast carcinoma with a long period of latency before presentation of the primary breast carcinoma $(69,70)$.

At these patients, the role of surgery is usually limited, resection has been considered in selected cases. Palliative surgery has not been shown to improve overall survival (5).

Considering the stage of generalized disease, the current trend is to manage the complications of gastric metastasis in a minim invasive manner: endoluminal stents for gastric outlet obstruction, endoscopic or endovascular therapy for tumoral bleeding $(50,71)$.
Another authors suggest that the surgery should be reduce to palliative bypass in those patients where minimally invasive measures not succeed or patients who develop complications $(5,39)$.

\section{Conclusion}

Given the low frequency of this type of tumour, latency in the development of gastric metastases, occurring especially after discontinuation of endocrine treatment are aspects that try to explain why confusion with a primary gastric tumor is possible. At the patients with a history of lobular breast cancer who have suspect gastric lesions we have to think about the possibility of distant metastasis. At these patients, obtaining pathologic material and biopsies interpretation can be a real challenge for getting a correct pathologic diagnosis, immunohistochemistry gives us definite diagnosis. The introduction of an endoscopic surveillance protocol for patients with lobular breast cancer could be a proposal for the detection of early gastric metastases allowing for appropriate therapy. An early diagnosis associated with the latest adjuvant systemic therapies and hormonal treatment, alone or in combination, may grant affected patients a remission with a reasonable survival rate and a reasonable quality of life.

\section{Conflicts of interest}

The authors declare that they have no conflicts of interest.

\section{References}

1. Siegel RL, Miller KD, Jemal A. Cancer statistics, 2016. CA Cancer J Clin. 2016; 66:7-30.

2. Kozłowski J, Kozłowska A, Kocki J. Breast cancer metastasis insight into selected molecular mechanisms of the phenomenon. Postepy Hig Med Dosw (Online). 2015;8(69):447-451.

3. Washington K, McDonagh D. Secondary tumors of the gastrointestinal tract: surgical pathologic findings and comparison with autopsy survey. Mod Pathol 1995;8: 427-433.

4. Jones GE, Strauss DC, Forshaw MJ, Deere H, Mahedeva U, Mason RC. Breast cancer metastasis to the stomach may mimic primary gastric cancer: report of two cases and review of literature. World J Surg Oncol.2007:5:75.

5. McLemore EC, Pockaj BA, Reynolds C, Gray RJ, Hernandez JL, 
Grant CS, et al. Breast cancer: presentation and intervention in women with gastrointestinal metastasis and carcinomatosis. Ann Surg Oncol. 2005; 12:886-894.

6. De Palma GD, Masone S, Rega M, Simeoli I, Donisi M, Addeo P et al. Metastatic tumors to the stomach: clinical and endoscopic features. World J Gastroenterol.2006;12:7326-7328.

7. Kobayashi O, Murakami H, Yoshida T, Cho H, Yoshikawa T, Tsuburaya $\mathrm{A}$ et al. Clinical diagnosis of metastatic gastric tumors: clinicopathologic findings and prognosis of nine patients in a cancer center. World J Surg. 2004; 28:548-551.

8. Ferri LE, Onerheim R, Emond C. Linitis plastica as the first indication of metastatic lobular carcinoma of the breast: case report and literature review.Can J Surg 1999;42: 466-469.

9. Schwarz RE, Klimstra DS, Turnbull AD. Metastatic breast cancer masquerading as gastrointestinal primary. Am J Gastroenterol 1998; 93:111-114.

10. Ferlicot S, Vincent-Salomon A, Médioni J, Genin P, Rosty C, Sigal-Zafrani $B$ et al. Wide metastatic spreading in infiltrating lobular carcinoma of the breast. Eur J Cancer.2004;40:336-341.

11. Matsuda I, Matsubara N, Aoyama N, Hamanaka M, Yamagishi D, Kuno $T$ et al. Metastatic lobular carcinoma of the breast masquerading as a primary rectal cancer. World $\mathrm{J}$ Surg Oncol 2012; 10:231.

12. Arpino G, Bardou VJ, Clark GM, Elledge RM. Infiltrating lobular carcinoma of the breast: tumor characteristics and clinical outcome. Breast Cancer Res.2004;6: R149-R156.

13. Geredeli C, Dogru O, Omeroglu E, Yilmaz F, Cicekci F. Gastric Metastasis of Triple Negative Invasive Lobular Carcinoma. Rare Tumors. 2015;7(2):5764. eCollection 2015 May 5.

14. Carcoforo P, Raiji MT, Langan RC, Lanzara S, Portinari M, Maestroni $U$ et al. Infiltrating lobular carcinoma of the breast presenting as gastrointestinal obstruction: a mini review. J Cancer. 2012;3:328-32.

15. Taal BG, Peterse $H$, Boot $H$. Clinical presentation, endoscopic features, and treatment of gastric metastases from breast carcinoma. Cancer. 2000;89(11):2214-2221

16. Kennecke H, Yerushalmi R, Woods R, Cheang MCU, Voduc D, Speers $\mathrm{CH}$ et al. Metastatic behavior of breast cancer subtypes. J Clin Oncol.2010;28:3271-3277.

17. Sertaç AG, Turgay Ş, Gökhan P, Alican G, Saffet Ç, Umut 0 , et al A Very Rare Reason for Gastric Perforation, Caused by Gastric Metastasis of Breast Cancer: Case Presentation Eur J Breast Health. 2019;15(1):59-62.

18. Joohyun $\mathrm{H}$, Youjin $\mathrm{K}$, Jangho $\mathrm{C}$. Clinical features and prognosis of breast cancer with gastric metastasis Oncol Lett.2019:17(2): 1833-1841.

19. Hong J, Kim Y, Cho J, Lim SW, Park SE, Kim HK, et al. Clinical features and prognosis of breast cancer with gastric metastasis. Oncol Lett. 2019 Feb;17(2):1833-1841. Epub 2018 Nov 23.

20. Tan L, Piao Y, Liu Z, Han T, Song F, Gao F, et al. Breast cancer metastasis to the stomach confirmed using gastroscopy: A case report. Oncol Lett. 2014;8(3):1205-1207.

21. Almubarak MM, Laé M, Cacheux W, de Cremoux P, Pierga JY, Reyal F, et al. Gastric metastasis of breast cancer: a single centre retrospective study. Dig Liver Dis. 2011;43(10):823-7.

22. Goss PE, Chambers AF. Does tumor dormancy offer a therapeutic target? Nat. Rev. Cancer, 2010;10:871-877.

23. Aguirre-Ghiso JA. Models, mechanisms and clinical evidence for cancer dormancy. Nat. Rev. Cancer, 2007; 7: 834-846.

24. Villa Guzmán JC, Espinosa J, Cervera R, Delgado M, Patón R, Cordero García JM. Gastric and colon metastasis from breast cancer: case report, review of the literature, and possible underlying mechanisms. Breast Cancer (Dove Med Press). 2016; 9:1-7. eCollection 2017.

25. De Gruttola I, Adil MT, D'Souza L, Jambulingam P, Whitelaw D. Perforated gastric carcinomatosis following invasive lobular cancer of the breast. Clin Case Rep. 2019;7(5):999-1002.
26. Tremblay F, Jamison B, Meterissian S. Breast cancer masquerading as a primary gastric carcinoma. J Gastrointest Surg.2002; 6:614-6.

27. Koike K, Kitahara K, Higaki M, Urata M, Yamazaki F, Noshiro H. Clinicopathological features of gastric metastasis from breast cancer in three cases. Breast Cancer. 2014; 21:629-634.

28. Hild C, Talha-Vautravers A, Hoefler P, Zirabe S, Bellocq JP, Mathelin C.Metastatic breast cancer to the stomach: An uncommon evolution of breast carcinoma. Gynecol Obstet Fertil. 2014; 42(1):47-50. Epub 2013 Dec 3.

29. Wong CS, Gumber A, Kiruparan P, Blackmore A. Gastric perforation secondary to metastasis from breast cancer. BMJ Case Rep. 2016. pii: bcr2016214865.

30. Ogawa M, Namikawa T, Oki T, Iwabu J, Munekage M, Maeda H, et al. Gastric outlet obstruction caused by metastatic tumor of the stomach originating from primary breast cancer: A case report. Mol Clin Oncol. 2018;9(5):523-526.

31. Critchley AC, Harvey J, Carr M, Iwuchukwu O. Synchronous gastric and colonic metastases of invasive lobular breast carcinoma: case report and review of the literature. Ann R Coll Surg Engl. 2011; 93(5): $449-50$

32. Hara F, Kiyoto S, Takabatake D, Takashima S, Aogi K, Ohsumi S, et al.Metastatic Breast Cancer to the Stomach Resembling Early Gastric Cancer. Case Rep Oncol. 2010;3(2):142-147.

33. Hwang SY, Ryu DY, Park JH, Lee DW, Lee DH, Kim TO, et al. A case of gastric metastasis of breast carcinoma resembling early gastric cancer. Korean J Gastroenterol. 2005;46(6):481-4.

34. Taal BG, den Hartog Jager FC, Steinmetz R, Peterse $H$. The spectrum of gastrointestinal metastases of breast carcinoma. 1. Stomach. Gastrointest Endosc. 1992;38:130-135.

35. Eo WK. Breast cancer metastasis to the stomach resembling early gastric cancer. Cancer Res Treat. 2008;40(4):207-10.

36. Whitty LA, Crawford DL, Woodland JH, Patel JC, Nattier B, Thomas CR Jr. Metastatic breast cancer presenting as linitis plastica of the stomach. Gastric Cancer. 2005;8(3):193-7.

37. Ushida Y, Yoshimizu S, Horiuchi Y, Yoshio T, Ishiyama A, Hirasawa $T$, et al. Clinicopathological Features of Metastatic Gastric Tumors Originating From Breast Cancer: Analysis of Eleven Cases. World J Oncol. 2018;9(4):104-109.

38. Skotnicki P, Sas-Korczynska B, Wohadlo L, Jakubowicz J, Blecharz $\mathrm{P}$, Reinfuss $\mathrm{M}$, et al. Distant metastases from invasive lobular breast carcinoma classic type - treatment and prognosis. Eur J Gynaecol Oncol. 2016;37(5):666-670.

39. Ciulla A, Castronovo G, Tomasello G, Maiorana AM, Russo L, Daniele $E$ et al. Gastric metastases originating from occult breast lobular carcinoma: Diagnostic and therapeutic problems. World J Surg Oncol 2008; 6:78.

40. Lorimier G, Binelli C, Burtin P, Maillart P, Bertrand G, Verriele V et al. Metastatic gastric cancer arising from breast carcinoma: endoscopic ultrasonographic aspects. Endoscopy 1998; 30:800-80.

41. Ulmer LL, Cormier I, Jha LK, Singh S, Fisher KW, Hewlett AT. Use of Endoscopic Ultrasound in a Diagnostic Dilemma: Metastatic Breast Cancer to the Stomach. Case Rep Gastrointest Med. 2018; 2018:2820352. eCollection 2018.

42. Kayılıŏglu SI, Akyol C, Esen E, Cansız-Ersöz C, Kocaay AF, Genç V, et al. Gastric metastasis of ectopic breast cancer mimicking axillary metastasis of primary gastric cancer. Case Rep Gastrointest Med. 2014;2014:232165.

43. Asmar N, Rey JF, Sattonnet C, Jerome J. Gastric Metastasis Mimicking Linitis Plastica 20 Years after Primary Breast Cancer. A Case Report J Gastrointestin Liver Dis. 2018;27(4):469-471.

44. Ghirarduzzi A, Sivelli R, Martella E, Bella M, De Simone B, Arcuri MF, et al. Gastric metastasis from breast carcinoma. Report of three cases, diagnostic-therapeutic critical close examination and literature review. Ann Ital Chir. 2010;81(2):141-6.

45. Pectasides D, Psyrri A, Pliarchopoulou K,Floros T, Papaxoinis G, Skondra $M$ et al. Gastric metastases originating from breast cancer: Report of 8 cases and review of the literature. Anticancer 
Res 2009; 29:4759-4763.

46. Kudo T, Matsumoto T, Nakamura S, Nakamura S, Esaki M, Yada S et al. Solitary minute metastasis from breast cancer mimicking primary intramucosal gastric signet-cell cancer. Gastrointest Endosc. 2005; 62:139-140.

47. Chu PG, Weiss LM. Immunohistochemical characterization of signet-ring cell carcinomas of the stomach, breast, and colon. Am J Clin Pathol 2004; 121:884-892.

48. D'Amato A, Pezzoli F, Balducci G, Bocchetti T, Ziparo V. Critical analysis of the long-term management of a case of cancer of the breast Chir Ital. 2006;58(3):377-81.

49. Pera M, Riera E, Lopez R, Viñolas N, Romagosa C, Miquel R. Metastatic carcinoma of the breast resembling early gastric carcinoma. Mayo Clin Proc. 2001 Feb;76(2):205-7.

50. Kim DH, Son SM, Choi YJ. Gastric metastasis from invasive lobular breast cancer, mimicking primary gastric cancer: A case report. Medicine (Baltimore). 2018;97(13):e0258.

51. Jmour 0, Belaïd A, Mghirbi F, Béhi K, Doghri R, Benna F.Gastric metastasis of bilateral breast cancer. JGastrointest Oncol. 2017; 8(1):E16-E20.

52. El-Hage A, Ruel C, Afif W, Wissanji H, Hogue JC, Desbiens C, et al. Metastatic pattern of invasive lobular carcinoma of the breastEmphasis on gastric metastases. J Surg Oncol. 2016;114(5): 543-547.

53. Tot T: The role of cytokeratins 20 and 7 and estrogen receptor analysis in separation of metastatic lobular carcinoma of the breast and metastatic signet ring cell carcinoma of the gastrointestinal tract. APMIS. 2000;108:467-472.

54. O'Connell FP, Wang HH, Odze RD. Utility of immunohistochemistry in distinguishing primary adenocarcinomas from metastatic breast carcinomas in the gastrointestinal tract. Arch Pathol Lab Med. 2005:129:338-347.

55. Zuhair AR, Maron AR. Occult bilateral invasive lobular carcinoma of the breast presenting as gastroduodenal metastases: a case report. Breast Dis. 2015;35(1):63-5.

56. Tremblay F, Jamison B, Meterissian S. Breast cancer masquerading as a primary gastric carcinoma. J Gastrointest Surg. 2002;6(4): 614-6.

57. van Velthuysen ML, Taal BG, van der Hoeven JJ, Peterse JL. Expression of oestrogen receptor and loss of E-cadherin are diagnostic for gastric metastasis of breast carcinoma. Histopathology. 2005;46:153-157.

58. Fernandes GS, Corrêa TS, Carvalho EP, Katz A, Hoff PM. Gastric and endobronchial metastases in a case of lobular breast cancer. Case Rep Oncol. 2013;6(3):555-60.
59. Rakha EA, Teoh TK, Lee AH, Nolan CC, Ellis IO, Green AR. Further evidence that E-cadherin is not a tumour suppressor gene in invasive ductal carcinoma of the breast: an immunohistochemical study. Histopathology 2013; 62:695-701.

60. Tavassoli FA, Devilee P. World Health Organization Classification of Tumours. Pathology and Genetics of Tumours of the Breast and Female Genital Organs. Lyon: IARC Press, 2003.

61. Early Breast Cancer Trialists' Collaborative Group (EBCTCG). Effects of chemotherapy and hormonal therapy for early breast cancer on recurrence and 15-year survival: an overview of the randomised trials. Lancet 2005;365:1687-1717.

62. Goss PE, Ingle JN, Martino S, Robert NJ, Muss HB, Piccart MJ. et al. A randomized trial of letrozole in postmenopausal women after five years of tamoxifen therapy for early-stage breast cancer. N. Engl. J. Med. 2003; 349:1793-1802.

63. Ulanja MB, Taha M, Al-Mashhadani A, Beutler BD, Al-Tekreeti M, Elliot $C$, et al. Gastrointestinal Bleed from Erosive Gastritis and Duodenitis: A Sentinel Event of Invasive Lobular Carcinoma of the Breast and a Diagnostic Dilemma. Cureus. 2018;10(6):e2757.

64. Xu L, Liang S, Yan N, Zhang L, Gu H, Fei X, et al. Metastatic gastric cancer from breast carcinoma: A report of 78 cases. Oncol Lett. 2017;14(4):4069-4077. Epub 2017 Aug 2.

65. Hayashi K, Sengoku N, Kosaka Y, Enomoto T, Kajita S, Kondo Y, et al. A long-term survival case of progressive breast cancer detected in gastric metastasis. Gan To Kagaku Ryoho. $2010 ; 37(12): 2756-9$.

66. Ayantunde AA, Agrawal A, Parsons SL, Welch NT. Esophagogastric cancers secondary to a breast primary tumor do not require resection. World J Surg. 2007:31(8):1597-601.

67. Katz A, Saad ED, Porter P, Pusztai L. Primary systemic chemotherapy of invasive lobular carcinoma of the breast. Lancet Oncol. 2007;8:55-62.

68. Hussain T, Elahi B, McManus P, Mahapatra T, Kneeshaw PJ. Gastric obstruction secondary to metastatic breast cancer: a case report and literature review. J Med Case Rep. 2012;6:232.

69. Buka D, Dvořák J, Richter I, Hadzi ND, Cyrany J. Gastric and Colorectal Metastases of Lobular Breast Carcinoma: A Case Report. Acta Medica (Hradec Kralove). 2016;59(1):18-21.

70. Dória MT, Maesaka JY, Martins SN, Filho Silveira TP, Boufelli G, Siqueira SA, et al. Gastric metastasis as the first manifestation of an invasive lobular carcinoma of the breast. Autops Case Rep. 2015;5(3):49-53

71. Ogawa M, Namikawa T, Oki T, Iwabu J, Munekage M, Maeda H, et al. Gastric outlet obstruction caused by metastatic tumor of the stomach originating from primary breast cancer: A case report. Mol Clin Oncol. 2018;9(5):523-526. 